九州大学学術情報リポジトリ

Kyushu University Institutional Repository

Effects of Dam Age, Lamb Gender, and Singleton or Twin Status on Body Size of Malya Lambs in Middle Anatolia, Turkey

Ci i lek, Süleyman

Department of Animal Breeding, Faculty of Veterinary Medicine, University of Kırıkkale

Gotoh, Takafumi

Kuju Agriculture Research Center, Kyushu University

https://doi.org/10.5109/1467643

出版情報: 九州大学大学院農学研究院紀要. 59 (2)，pp.313-320，2014-08-29. Faculty of Agriculture, Kyushu University

バージョン :

権利関係 : 


\title{
Effects of Dam Age, Lamb Gender, and Singleton or Twin Status on Body Size of Malya Lambs in Middle Anatolia, Turkey
}

\author{
Süleyman ÇiLEK ${ }^{1}$ and Takafumi GOTOH ${ }^{2}$
}

\author{
${ }^{1}$ Department of Animal Breeding, Kırıkkale University, 71450, Kırıkkale, Turkey \\ ${ }^{2}$ Kuju Agricultural Research Center, Faculty of Agriculture, \\ Kyushu University, Kuju, Oita, Japan \\ (Received April 25, 2014 and accepted May 12, 2014)
}

\begin{abstract}
The effects of dam age, lamb gender, and singleton or twin status on lamb body size and growth were investigated in Malya lambs in Middle Anatolia, Turkey. Data were obtained from 302 lambs from an elite Malya sheep flock. Wither height, body length, rump height, rump length, back height, rump width, and front cannon bone circumference were recorded. The least square means method was used to determine factors that significantly affected body size of the lambs. General linear model in Minitab packet program was used to test the effects of variables on body size measurements.

Least square means for wither height at birth and 1,2, 3, 4, 6, 9 and 12 months of age were 40.13, $48.09,55.07,60.16,64.99,70.23,74.45$ and $76.66 \mathrm{~cm}$, respectively. Dam age did not significantly affect body size parameters during the first year of life, except for rump height and front cannon bone circumference. Male lambs were significantly larger between birth and 12 months of age than females $(\mathrm{P}<0.05)$. Singleton lambs were significantly larger than twins until 6 months of age $(P<0.05)$, but this effect was not significant after 6 months of age. It is suggested that there might be compensatory growth in twin lambs after weaning. In particular, twins born from 2 -year-old dams show strong compensatory growth post-weaning. If farmers are able to ensure twin lamb survival until weaning age, they can expect compensatory growth after 9 months of age.
\end{abstract}

Key words: Malya lamb, body size, growth, dam age, gender, birth type, singleton, twin

\section{INTRODUCTION}

Successful sheep breeding programs take into account geographical considerations, economic conditions, and sheep breed characteristics. In the Central and Eastern Anatolia regions of Turkey, domestic sheep need to provide adequate meat and wool yields while living in a harsh climate with poor pasture conditions (Kaymakçı and Sönmez 1992; Akçapınar 1994).

Improvements in the sheep production system began in Turkey after establishment of the Turkish Republic in 1923 year. Crossbreeding with Merino rams was used to improve the production and quality of the fleece of local breeds. Deutsches Merinofleischschaf (German Whiteheaded Mutton), sheep known for their rapid growth and fecundity, were imported to Turkey in 1934 and crossbred with domestic sheep. This addition of foreign breeding stock resulted in the creation of new breeds, such as the Karacabey Merino (West Anatolia Merino), Central Anatolia Merino (Konya Merino) and Malya sheep.

The Malya sheep, a breed with good meat and wool production, was developed by crossbreeding Deutsches Merinofleischschaf with native fat-tailed Akkaraman sheep and crossbreds have been improved by subsequent selection for type stabilization since 1959 at the Malya state farm (Figure 1). Its genotype is approximately $65 \%$

\footnotetext{
University of Kırıkkale, Faculty of Veterinary Medicine, Department of Animal Breeding, Yahşihan, 71451 Kırıkkale, Turkey

${ }^{2}$ Kuju Agriculture Research Center, Kyushu University, Oita, 878-0201, Japan

* Corresponding author (E-mail: gotoh@farm.kyushu-u.ac.jp)
}

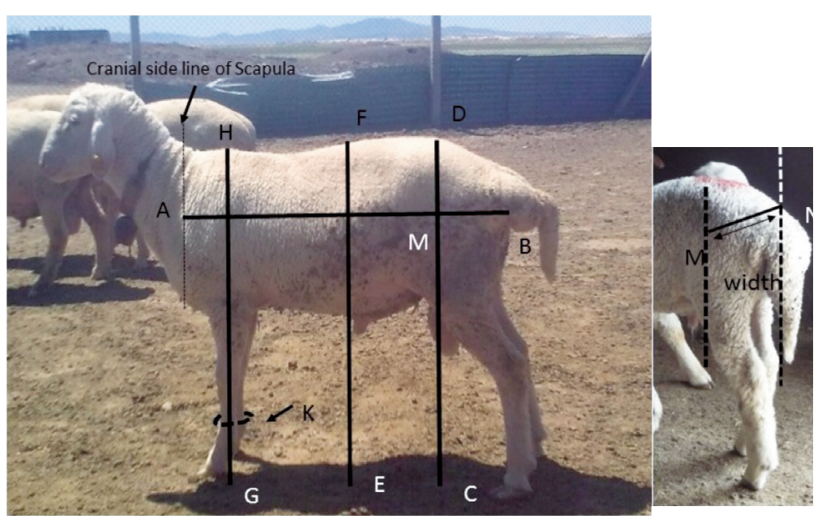

Fig. 1. Body size measurements used in this study. A-B: Body length, C-D: Rump height, E-F: Back height, G-H: Wither height, M-B: Rump length, M-N: Rump width, K: Front cannon bone circumference. (Picture taken by Dr. Süleyman ÇİLEK).

Akkaraman and 35\% Deutsches Merinofleischschaf. When compared with the Akkaraman sheep, which has a characteristic fat tail, the Malya sheep have a semi-fat tail and fine, high quality fleece (Çolakoğlu and Özbeyaz, 1999). Since the creation of the Malya breed, the Akkaraman and Malya genotypes have been investigated in a limited number of studies (Düzgüneş and Pekel, 1966; Çolakoğlu and Özbeyaz, 1999). Over the past 50 years, Malya sheep have been bred as a closed flock, only at the Malya state farm in Turkey. Because Malya sheep are heterozygote and product of cross-breeding, genetic drift can result in changes in production traits; thus it is important to monitor breed performance. 
Bela and Haile (2009) reported that singleton lambs were born larger than twins, and that this size difference generally decreased by 300 days of age in lambs from tropical regions. Ch'ang and Rae (1970) reported that pre-weaning growth of twins was slower than that of singleton lambs, and that twins exhibited post-weaning compensatory growth. They also found that age of the dam moderately affected the weaning weight of lambs. In this study, we investigated the effects of dam age, lamb gender, and singleton or twin status on the body size and growth of Malya lambs in Middle Anatolia, Turkey.

\section{MATERIALS AND METHODS}

This study was carried out on an elite flock of Malya sheep at the Malya State Farm, which is connected to the General Directorate of Agricultural Enterprises in Middle Anatolia, Turkey. Malya state farm, $27 \mathrm{~km}$ north-east of the city of Kırşehir, $55 \mathrm{~km}$ south of the town of Yerköy, $25 \mathrm{~km}$ to the north of the town of Mucur, in Middle Anatolia in Turkey, which have steppe climate and is very suitable for sheep breeding. This farm is located in a region with a steppe climate typical of Middle Anatolia sheep breeding areas. This study was conducted between February 2012 and February 2013, and the lambing period Lamb births was in February 2012.

Experimental lambs were habituated and started to lamb starter feed after 15 days of age for subsequent (later) intensive feeding. They were nursed by their dams twice per day until weaning at 4 months of age. At 40 days of age, $250 \mathrm{~g} /$ day lamb starter feed was added to their diet; this was subsequently increased to $300 \mathrm{~g} /$ day until 4 months of age. After weaning, the animals grazed on pasture and fed approximately $800 \mathrm{~g} /$ day of additional feed.

Male lambs excess to the breeding needs of the farm were sold at 7 months of age; therefore, this study followed the female lambs and the remaining male lambs until 1 year of age. The following body measurements were obtained from 302 lambs (data shown in Table 1): 1) body length: the horizontal distance between the caput humeri and tuber ischium; 2) wither height: the vertical distance between highest point of the withers and flat ground; 3) back height: the vertical distance between the highest point of the back and flat ground; 4) rump height: the vertical distance between the highest point of the sacrum and flat ground; 5) rump length: the horizontal distance between the tuber coxae and tuber ischium; 6) rump width: the horizontal distance between the left and right tuber coxae (known as front rump width); 7) front cannon bone circumference: the circumference of the thinnest part of the distal limb (measured over the metacarpi) (Biylkoğlu 2009, Koncagül et al., 2012). All measurements were taken with the lambs standing squarely on all four legs. Height measurements, rump width, and body length were taken using a graduated measuring stick. Front cannon bone circumference and rump length were measured using a measuring tape. These body measurements were taken at birth and 30, $60,90,120,180,270$ and 365 days of age.
Table 1. Study animals

\begin{tabular}{|c|c|c|c|c|c|}
\hline Traits & \multicolumn{5}{|c|}{ item } \\
\hline Mother's age (year) & \multirow[t]{2}{*}{2} & \multirow[t]{2}{*}{3} & \multirow[t]{2}{*}{4} & & 5 \\
\hline \multicolumn{2}{|l|}{ month of age } & & & & \\
\hline 0 & 101 & 62 & 75 & & 64 \\
\hline 1 & 95 & 59 & 71 & & 61 \\
\hline 2 & 91 & 56 & 70 & & 57 \\
\hline 3 & 88 & 54 & 70 & & 56 \\
\hline 4 & 84 & 54 & 68 & & 56 \\
\hline 6 & 81 & 51 & 68 & & 51 \\
\hline 9 & 51 & 34 & 35 & & 32 \\
\hline 12 & 50 & 31 & 33 & & 31 \\
\hline Birth type & \multicolumn{2}{|c|}{ Singleton } & \multicolumn{3}{|c|}{ Twin } \\
\hline \multicolumn{6}{|l|}{ month of age } \\
\hline 0 & \multicolumn{2}{|c|}{150} & \multicolumn{3}{|c|}{152} \\
\hline 1 & \multicolumn{2}{|c|}{141} & \multicolumn{3}{|c|}{145} \\
\hline 2 & \multicolumn{2}{|c|}{137} & \multicolumn{3}{|c|}{137} \\
\hline 3 & \multicolumn{2}{|c|}{134} & \multicolumn{3}{|c|}{134} \\
\hline 4 & \multicolumn{2}{|c|}{130} & \multicolumn{3}{|c|}{132} \\
\hline 6 & \multicolumn{2}{|c|}{123} & \multicolumn{3}{|c|}{128} \\
\hline 9 & \multicolumn{2}{|c|}{88} & \multicolumn{3}{|c|}{64} \\
\hline 12 & \multicolumn{2}{|c|}{84} & \multicolumn{3}{|c|}{61} \\
\hline Gender & \multicolumn{2}{|c|}{ Female } & \multicolumn{3}{|c|}{ Male } \\
\hline \multicolumn{6}{|l|}{ month of age } \\
\hline 0 & \multicolumn{2}{|c|}{161} & \multicolumn{3}{|c|}{141} \\
\hline 1 & \multicolumn{2}{|c|}{154} & & 132 & \\
\hline 2 & & & & 124 & \\
\hline 3 & & & & 123 & \\
\hline 4 & & & & 122 & \\
\hline 6 & & & & 116 & \\
\hline 9 & & & & 23 & \\
\hline 12 & & & & 20 & \\
\hline
\end{tabular}

Statistical analyses were performed using Minitab (Minitab, 1998). The effects of dam age, lamb gender, and singleton or twin status on body size and growth were investigated. The least square means method was used to identify factors that significantly influenced body size at each measurement time. Duncan's multiple range tests were used to perform multiple comparisons in important subgroups (Duncan, 1955).

\section{RESULTS AND DISCUSSION}

\section{Effect of dam age on body size and growth}

Wither height at birth was significantly smaller in the lambs from 2-year-old dams than in those from dams older than 2 years $(\mathrm{P}<0.05$; Table 2$)$. The offspring of 3- and 5-year-old dams had a greater wither height at 1 months of age than the offspring of $2-$ and 4-year-old dams $(\mathrm{P}<0.05)$. There were no significant between-dam age group differences in offspring wither 
height at any other measurement time. Body length at 270 days of age was significantly larger in offspring of 2-year-old dams than in those of 3- and 4-year-old dams $(\mathrm{P}<0.05$; Table 2). There were no significant between-dam age group differences in lamb body length at any other measurement time.

Rump width at 270 days of age was greatest in lambs from 2-year-old dams, intermediate in lambs from 3- and 5-year-old dams, and smallest in lambs from 4-year-old dams $(\mathrm{P}<0.05$; Table 2). There were no significant

Table 2. Comparison of body length, wither height, back height, rump height, rump length, rump width and front cannon bone circumference among different dam age groups of Malya lambs

\begin{tabular}{|c|c|c|c|c|c|c|}
\hline Mother age & 2 & 3 & 4 & 5 & means & $\mathrm{P}$ value \\
\hline \multicolumn{7}{|c|}{ Body length $(\mathrm{cm})$} \\
\hline \multicolumn{7}{|l|}{ month of age } \\
\hline 0 & 32.57 & 32.67 & 33.06 & 33.02 & 32.83 & 0.262 \\
\hline 1 & 46.15 & 46.82 & 46.32 & 47.12 & 46.60 & 0.123 \\
\hline 2 & 52.48 & 53.13 & 53.10 & 53.13 & 52.96 & 0.499 \\
\hline 3 & 57.72 & 58.58 & 58.42 & 58.36 & 58.27 & 0.474 \\
\hline 4 & 64.44 & 64.62 & 64.73 & 64.33 & 64.53 & 0.918 \\
\hline 6 & 70.38 & 69.37 & 69.70 & 71.01 & 70.12 & 0.064 \\
\hline 9 & $75.15^{\mathrm{a}}$ & $73.03^{\mathrm{b}}$ & $72.99^{b}$ & $74.45^{\mathrm{ab}}$ & 73.90 & 0.008 \\
\hline 12 & 76.69 & 75.64 & 75.63 & 77.13 & 76.27 & 0.241 \\
\hline \multicolumn{7}{|c|}{ Wither height $(\mathrm{cm})$} \\
\hline \multicolumn{7}{|l|}{ month of age } \\
\hline 0 & $39.66^{\mathrm{b}}$ & $40.17^{\mathrm{ab}}$ & $40.54^{\mathrm{a}}$ & $40.18^{\mathrm{ab}}$ & 40.13 & 0.016 \\
\hline 1 & $47.71^{\mathrm{b}}$ & $48.45 \mathrm{a}$ & $47.74^{b}$ & $48.48 \mathrm{a}$ & 48.09 & 0.046 \\
\hline 2 & 54.58 & 55.50 & 55.11 & 55.08 & 55.07 & 0.198 \\
\hline 3 & 59.60 & 60.69 & 60.11 & 60.26 & 60.16 & 0.177 \\
\hline 4 & 64.71 & 65.34 & 65.28 & 64.62 & 64.99 & 0.395 \\
\hline 6 & 70.18 & 70.27 & 70.05 & 70.38 & 70.23 & 0.946 \\
\hline 9 & 75.32 & 74.19 & 74.00 & 74.28 & 74.45 & 0.113 \\
\hline 12 & 77.43 & 76.35 & 76.09 & 76.75 & 76.66 & 0.184 \\
\hline \multicolumn{7}{|c|}{ Back height (cm) } \\
\hline \multicolumn{7}{|l|}{ month of age } \\
\hline 0 & 39.88 & 40.41 & 40.32 & 40.01 & 40.15 & 0.629 \\
\hline 1 & 47.87 & 48.46 & 47.85 & 48.32 & 48.13 & 0.290 \\
\hline 2 & 54.88 & 55.80 & 55.36 & 55.36 & 55.35 & 0.254 \\
\hline 3 & 59.95 & 61.12 & 60.64 & 60.63 & 61.06 & 0.175 \\
\hline 4 & 65.16 & 65.48 & 64.89 & 64.90 & 65.11 & 0.893 \\
\hline 6 & 70.57 & 70.40 & 70.36 & 70.78 & 70.53 & 0.892 \\
\hline 9 & 75.57 & 74.26 & 74.27 & 74.39 & 74.62 & 0.069 \\
\hline 12 & 77.56 & 76.41 & 76.27 & 76.76 & 76.75 & 0.130 \\
\hline \multicolumn{7}{|c|}{ Rump heigth (cm) } \\
\hline \multicolumn{7}{|l|}{ month of age } \\
\hline 0 & 40.47 & 40.55 & 41.21 & 41.10 & 40.83 & 0.169 \\
\hline 1 & 48.43 & 48.93 & 48.62 & 49.14 & 48.78 & 0.296 \\
\hline 2 & 55.48 & 56.22 & 55.77 & 55.85 & 55.83 & 0.469 \\
\hline 3 & 60.37 & 61.49 & 61.18 & 61.19 & 61.06 & 0.175 \\
\hline 4 & 65.69 & 65.67 & 65.58 & 65.41 & 64.99 & 0.395 \\
\hline 6 & 70.53 & 70.53 & 70.12 & 70.88 & 70.51 & 0.663 \\
\hline 9 & 75.56 & 74.06 & 74.09 & 74.35 & 74.51 & 0.055 \\
\hline 12 & 77.49 & 76.39 & 75.88 & 76.74 & 76.62 & 0.064 \\
\hline
\end{tabular}

Data are least square means. ${ }^{a, b}$ significant difference between ages of dams $(\mathrm{P}<0.05)$ 
Table 2. (Continued)

\begin{tabular}{|c|c|c|c|c|c|c|}
\hline Mother age & 2 & 3 & 4 & 5 & means & $P$ value \\
\hline \multicolumn{7}{|c|}{ Rump length (cm) } \\
\hline \multicolumn{7}{|l|}{ month of age } \\
\hline 0 & 12.39 & 12.55 & 13.12 & 12.54 & 12.65 & 0.074 \\
\hline 1 & 16.60 & 16.96 & 16.84 & 16.79 & 16.80 & 0.296 \\
\hline 2 & 18.73 & 19.10 & 19.04 & 18.91 & 18.95 & 0.195 \\
\hline 3 & 19.94 & 20.25 & 20.19 & 20.23 & 20.15 & 0.311 \\
\hline 4 & 22.44 & 22.59 & 22.37 & 22.23 & 22.41 & 0.472 \\
\hline 6 & 24.62 & 24.67 & 24.59 & 24.75 & 24.66 & 0.925 \\
\hline 9 & 27.03 & 26.78 & 26.54 & 26.79 & 26.78 & 0.316 \\
\hline 12 & $27.81^{\mathrm{a}}$ & $27.50^{\mathrm{ab}}$ & $27.03^{\mathrm{b}}$ & $27.24^{\mathrm{b}}$ & 27.39 & 0.013 \\
\hline \multicolumn{7}{|c|}{ Rump width (cm) } \\
\hline \multicolumn{7}{|l|}{ month of age } \\
\hline 0 & 7.78 & 8.55 & 8.08 & 7.91 & 8.08 & 0.114 \\
\hline 1 & 11.72 & 12.01 & 11.77 & 11.82 & 11.83 & 0.235 \\
\hline 2 & 12.65 & 12.59 & 12.51 & 12.67 & 12.61 & 0.797 \\
\hline 3 & 13.11 & 13.37 & 13.19 & 13.34 & 13.25 & 0.354 \\
\hline 4 & 15.39 & 15.62 & 15.35 & 15.25 & 15.40 & 0.272 \\
\hline 6 & 17.23 & 17.14 & 16.90 & 17.39 & 17.16 & 0.109 \\
\hline 9 & $18.05^{\mathrm{a}}$ & $17.63^{\mathrm{b}}$ & $17.44^{\mathrm{c}}$ & $17.61^{\mathrm{b}}$ & 17.68 & 0.024 \\
\hline 12 & 17.97 & 17.57 & 17.58 & 17.69 & 17.70 & 0.246 \\
\hline \multicolumn{7}{|c|}{ Front cannon bone circumstance $(\mathrm{cm})$} \\
\hline \multicolumn{7}{|l|}{ month of age } \\
\hline 0 & $6.18^{\mathrm{b}}$ & $6.31^{\mathrm{a}}$ & $6.28^{\mathrm{a}}$ & $6.31^{\mathrm{a}}$ & 6.27 & 0.032 \\
\hline 1 & 6.76 & 6.83 & 6.85 & 6.82 & 6.81 & 0.339 \\
\hline 2 & 6.83 & 6.94 & 6.95 & 6.94 & 6.91 & 0.188 \\
\hline 3 & 7.16 & 7.19 & 7.19 & 7.24 & 7.19 & 0.823 \\
\hline 4 & 7.99 & 8.05 & 7.96 & 7.98 & 7.99 & 0.769 \\
\hline 6 & 7.91 & 7.92 & 7.86 & 7.93 & 7.91 & 0.781 \\
\hline 9 & 8.20 & 7.99 & 8.08 & 8.04 & 8.07 & 0.091 \\
\hline 12 & $8.23^{\mathrm{a}}$ & $8.05^{b}$ & $8.04^{\mathrm{b}}$ & $8.10^{\mathrm{ab}}$ & 8.10 & 0.047 \\
\hline
\end{tabular}

Data are least square means. ${ }^{a, b}$ significant difference between ages of dams $(P<0.05)$

between-dam age group differences in the rump width of the offspring at any other time point. There were significant differences in rump length only at 365 days of age, with the offspring of 2-year-old dams having significantly longer rumps than those from 4- and 5-year-old dams $(\mathrm{P}=0.013)$; Table 2$)$. The front cannon bone circumference of offspring at birth was significantly smaller in lambs from 2-year-old dams than in lambs from 3-, 4- and 5-year-old dams ( $\mathrm{P}<0.05$; Table 2$)$. Conversely, at 365 days of age the circumference of the front cannon bone was significantly larger in lambs from 2-year-old dams than in lambs from 3- and 4-year-old dams $(\mathrm{P}<$ 0.05).

Based on these results, we suggest that dam age (from 2 to 5 years) does not strongly affect the first year growth performance of Malya lambs, with the exception of rump length and front cannon bone circumference.

\section{Effect of singleton or twin status on body size and growth}

Wither height, rump height, back height and rump length were significantly higher in singleton lambs than twins until 180 days of age (Table 3). However, at 270 and 365 days of age, there were no significant differences between singleton and twin lambs in any of these parameters (Table 3). Singleton lambs also had greater body length until 120 days of age relative to twin lambs $(0,30,60$ and 120 days of age: $\mathrm{P}<0.001 ; 90$ days of age: $\mathrm{P}<0.05)$. Body length did not differ between singleton and twin lambs at 180, 270, or 365 days of age.

Rump width and front cannon bone circumference at birth were not significantly different between singleton and twin lambs (Table 3). However, from 30 until 120 days of age, singleton lambs had wider rumps than twins (30, 60 and 120 days of age: $\mathrm{P}<0.001 ; 90$ days of age: $\mathrm{P}=0.01$; Table 3 ). Front cannon bone circumference 
Table 3. Comparison of body length, wither height, back height, rump height, rump length, rump width and front cannon bone circumference between singleton and twin, and male and female, in Malya lambs

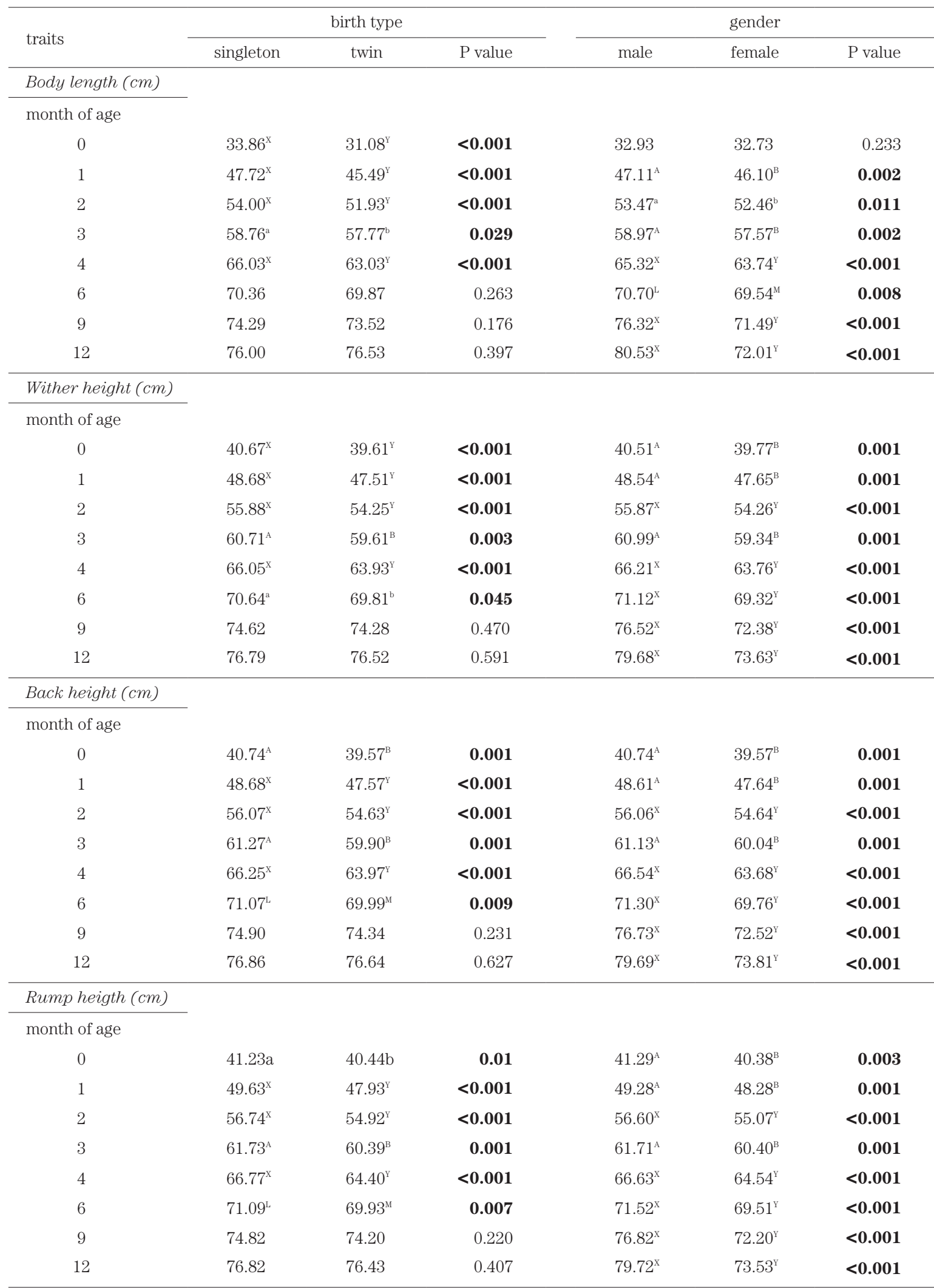

Data are least square means. ${ }^{a, b}$ significant difference between single and twin or male and female $(\mathrm{P}<0.05)$

${ }_{A, B}$ significant difference between single and twin or male and female $(P<0.005)$

${ }^{\mathrm{X}, \mathrm{Y}}$ significant difference between single and twin or male and female $(\mathrm{P}<0.001)$

${ }^{\mathrm{L}, \mathrm{M}}$ significant difference between single and twin or male and female $(\mathrm{P}<0.01)$ 
Table 3. (Continued)

\begin{tabular}{|c|c|c|c|c|c|c|}
\hline \multirow{2}{*}{ traits } & \multicolumn{3}{|c|}{ birth type } & \multicolumn{3}{|c|}{ gender } \\
\hline & singleton & twin & P value & male & female & $\mathrm{P}$ value \\
\hline \multicolumn{7}{|c|}{ Rump length $(\mathrm{cm})$} \\
\hline \multicolumn{7}{|c|}{ month of age } \\
\hline 0 & $13.06^{\mathrm{x}}$ & $12.24^{\mathrm{Y}}$ & $<0.001$ & 12.68 & 12.63 & 0.828 \\
\hline 1 & $17.20^{\mathrm{x}}$ & $16.40^{\mathrm{Y}}$ & $<0.001$ & $17.05^{\mathrm{A}}$ & $16.55^{\mathrm{B}}$ & 0.001 \\
\hline 2 & $19.26^{\mathrm{x}}$ & $18.63^{\mathrm{Y}}$ & $<0.001$ & $19.17^{\mathrm{A}}$ & $18.73^{\mathrm{B}}$ & 0.001 \\
\hline 3 & $20.45^{\mathrm{x}}$ & $19.86^{\mathrm{Y}}$ & $<0.001$ & $20.38^{\mathrm{A}}$ & $19.93^{\mathrm{B}}$ & 0.002 \\
\hline 4 & $22.87^{\mathrm{x}}$ & $21.94^{\mathrm{Y}}$ & $<0.001$ & $22.67^{\mathrm{A}}$ & $22.15^{\mathrm{B}}$ & 0.001 \\
\hline 6 & $24.90^{\mathrm{L}}$ & $24.41^{\mathrm{M}}$ & 0.005 & $25.11^{x}$ & $24.20^{\mathrm{Y}}$ & $<0.001$ \\
\hline 9 & 26.86 & 26.71 & 0.477 & $27.71^{x}$ & $25.86^{\mathrm{Y}}$ & $<0.001$ \\
\hline 12 & 27.44 & 27.35 & 0.648 & $28.81^{x}$ & $25.97^{\mathrm{Y}}$ & $<0.001$ \\
\hline \multicolumn{7}{|c|}{ Rump Width (cm) } \\
\hline \multicolumn{7}{|c|}{ month of age } \\
\hline 0 & 8.31 & 7.85 & 0.053 & 8.08 & 8.08 & 0.981 \\
\hline 1 & $12.27^{\mathrm{x}}$ & $11.39^{\mathrm{Y}}$ & $<0.001$ & $11.94^{\mathrm{a}}$ & $11.72^{\mathrm{b}}$ & 0.033 \\
\hline 2 & $12.88^{\mathrm{x}}$ & $12.33^{\mathrm{Y}}$ & $<0.001$ & 12.69 & 12.52 & 0.185 \\
\hline 3 & $13.41^{\mathrm{L}}$ & $13.09^{\mathrm{M}}$ & 0.008 & 13.29 & 13.21 & 0.492 \\
\hline 4 & $15.68^{\mathrm{x}}$ & $15.12^{\mathrm{Y}}$ & $<0.001$ & $15.54^{\mathrm{a}}$ & $15.27^{\mathrm{b}}$ & 0.032 \\
\hline 6 & 17.15 & 17.18 & 0.800 & $17.67^{\mathrm{x}}$ & $16.66^{\mathrm{Y}}$ & $<0.001$ \\
\hline 9 & 17.73 & 17.64 & 0.565 & $18.14^{\mathrm{x}}$ & $17.23^{\mathrm{Y}}$ & $<0.001$ \\
\hline 12 & 17.87 & 17.53 & 0.053 & $18.46 \mathrm{x}$ & $16.94 \mathrm{Y}$ & $<0.001$ \\
\hline \multicolumn{7}{|c|}{ Front cannon bone circumstance $(\mathrm{cm})$} \\
\hline \multicolumn{7}{|c|}{ month of age } \\
\hline 0 & 6.31 & 6.23 & 0.052 & $6.33^{\mathrm{A}}$ & $6.21^{\mathrm{B}}$ & 0.002 \\
\hline 1 & $6.95^{\mathrm{x}}$ & $6.68^{\mathrm{Y}}$ & $<0.001$ & $6.92^{x}$ & $6.70^{\mathrm{Y}}$ & $<0.001$ \\
\hline 2 & $7.11^{\mathrm{x}}$ & $6.72^{\mathrm{Y}}$ & $<0.001$ & $7.03^{\mathrm{x}}$ & $6.80^{\mathrm{Y}}$ & $<0.001$ \\
\hline 3 & $7.34^{\mathrm{x}}$ & $7.05^{\mathrm{Y}}$ & $<0.001$ & $7.31^{x}$ & $7.08^{Y}$ & $<0.001$ \\
\hline 4 & $8.14^{\mathrm{x}}$ & $7.85^{\mathrm{Y}}$ & $<0.001$ & $8.22^{\mathrm{x}}$ & $7.77^{\mathrm{Y}}$ & $<0.001$ \\
\hline 6 & $7.98^{\mathrm{L}}$ & $7.83^{\mathrm{M}}$ & 0.009 & $8.21^{x}$ & $7.60^{\mathrm{Y}}$ & $<0.001$ \\
\hline 9 & 8.13 & 8.02 & 0.102 & $8.42^{x}$ & $7.73^{\mathrm{Y}}$ & $<0.001$ \\
\hline 12 & 8.13 & 8.08 & 0.384 & $8.59 \mathrm{x}$ & $7.62^{\mathrm{Y}}$ & $<0.001$ \\
\hline
\end{tabular}

Data are least square means. ${ }^{a, b}$ significant difference between single and twin or male and female $(\mathrm{P}<0.05)$

$A, B$ significant difference between single and twin or male and female $(\mathrm{P}<0.005)$

$\mathrm{X}, \mathrm{Y}$ significant difference between single and twin or male and female $(\mathrm{P}<0.001)$

${ }^{\mathrm{L}, \mathrm{M}}$ significant difference between single and twin or male and female $(\mathrm{P}<0.01)$

from 30 to 180 days of age was significantly larger in singletons than in twins (30, 60, 90 and 120 days of age: $\mathrm{P}<0.001 ; 180$ days of age: $\mathrm{P}<0.01$; Table 3 ).

These results indicate that singleton or twin status strongly affected growth performance until 6 months of age. Almost all body size measurements were significantly larger in singleton lambs than in twins until approximately 6 months of age (Table 3); however, after 6 months these differences disappeared. At 12 months of age, body size was similar between singleton and twin lambs.

\section{Effect of lamb gender on body size and growth}

Male lambs had greater wither height, rump height, back height and front cannon bone circumference from birth to 365 days of age than females (Table 3). Although, at birth, body and rump length did not significantly differ between males and females, males had greater body and rump lengths than females from 30 to 365 days of age (Table 3). Rump width also did not differ between genders at birth, but males had significantly wider rumps at 30,120, 180, 270 and 365 days of age than did females $(\mathrm{P}=0.033,0.032,<0.001,<0.001$ and $<0.001$, respectively; Table 3 ). These results clearly suggest that males have larger body sizes than females during the first year of life. Although the rump width of males was still greater than that of females until 6 months of age, the difference was not as statistically significant as that 
seen in other body parts. After 6 months of age, the growth in rump width accelerated in males relative to females.

The continued genetic improvement of sheep breeds is very important for the sustainability of lamb production and management. The data we present in this study are from 302 Malya lambs, and provide practical and reliable information about their growth and the factors influencing their growth performance.

Pekel and Düzgüneş (1966) reported that the average wither height of Malya lambs was $39.94 \mathrm{~cm}$ at birth, which is almost identical to our result of $40.13 \mathrm{~cm}$ (Table 2). Meanwhile, Şireli and Ertuğrul (2004) and Işık (2010) indicated that it was about $34 \mathrm{~cm}$. At 3 months of age, wither height was $60.16 \mathrm{~cm}$ in this study. Pekel and Düzgüneş (1966) reported that wither height of Malya lamb was $51.96 \mathrm{~cm}$ at 3 months of age, which is considerably smaller than our result. The wither height at 3 months of age of the Malya lambs in our study was larger than that reported for Akkaraman $(51.09 \mathrm{~cm}$; Şireli and Ertuğrul, 2004, Karakuş, 2007) and Bafra lambs (54.81 cm; Işık, 2010). At 6 months of age we found an average wither height of $70.23 \mathrm{~cm}$ (Table 2). This was larger than previous reported in Malya lambs $(58.66 \mathrm{~cm}$; Pekel and Düzgüneş, 1966) and other breeds at the same age, such as Akkaraman lambs (58.37-60.83 cm; Esen and Ylldız, 2000; Şireli and Ertuğrul, 2004; Karakuş, 2007), Merino lambs (64.26 cm; Çetin and Akçapınar, 2005) and Bafra lambs (54.04 cm; Işık, 2010). The average wither height at 9 months of age in the Malya lambs in our study was $74.45 \mathrm{~cm}$ (Table 2). Compared with other breeds at 9 months of age, this was higher than Merino lambs (65.72 cm; Çetin and Akçapınar, 2005), and Akkaraman lambs (61.87 cm; Karakuş 2007). Finally, the average wither height at 12 months of age was $76.66 \mathrm{~cm}$. This value was also higher than for Merino lambs $(70.79 \mathrm{~cm}$; Çetin and Akçapınar, 2005) and Akkaraman lambs (64.97 cm; Karakuş 2007).

The frame size of Malya lambs has become larger than reported previously; wither height, body length, back height, rump width, and front cannon bone circumference were all larger in the lambs in our study than reported by Pekel and Düzgüneş in 1966. This suggests that feeding and lamb care practices have improved, or that selection has improved the Malya breed resulting in its larger size relative to other breeds.

The offspring of 2-year-old dams had small wither heights and front cannon bone circumferences. This might be explained by the lower milk production, lower maternal ability, and smaller uterus size of these younger dams. Also, previous reports have suggested that, because young dams have not yet completed their own growth and development, their lambs may not grow to full size (Rashidi et al., 2008, Hyatt et al., 2010, Baneh et al. 2013). Older dams have larger uteri, more energy available for lamb growth, better maternal ability, and higher milk yields, which may account for the larger size of their lambs. The positive effects of increased dam age are likely maintained until weaning. After weaning, the larger body size of lambs from younger dams may be explained by compensatory growth as reported by Akçapınar and Özbeyaz (1999), in which the lambs that started out lighter than their peers compensate for early malnourishment by faster growth later in development.

In general, lamb gender significantly affected all body measurements at all age points until 12 months of age, with male lambs being larger than females. This may be a result of the presence of the $\mathrm{Y}$ chromosome and higher androgen levels in males. Increased differences between male and female lambs after weaning may be the result of testosterone effects on growth. The physiological aspects of the hormonal control of growth and development are a topic for further research.

Although the effect of singleton or twin status on body length was significant before weaning $(\mathrm{P}<0.05)$, this effect did not remain significant after weaning $(\mathrm{P}>0.05)$, likely as a result of compensatory growth of twin lambs. Because twin lambs may have less milk available from their dam, they may eat more roughage earlier than singleton lambs. Thus, twin lambs may be less stressed at weaning than singleton lambs. Generally, the effect of twin or singleton status on all pre-weaning body measurements was significant, with singleton lambs being larger. The similarity in the body size of singleton and twin lambs after weaning can be explained by compensatory growth after weaning.

Customarily, twin lambing is not preferred by breeders because of the greater metabolic stress to the dam, slow lamb growth, and increased incidence of lamb death associated with twinning. However, we have shown that twin lambs drink less milk but attain a body size similar to that of singleton lambs by 12 months of age. As twin lambs may eat more roughage and drink less milk before weaning, they may have a more sophisticated rumen rich in microbial flora (Lu et al., 1988). If measures are taken to ensure twin lamb survival until weaning, their accelerated growth during the post-weaning period could result in twin lambs providing a profitable means of increasing production.

Compensatory growth refers to the accelerated growth and rapid weight gain that follows the end of a period of reduced nutrient intake. Twin lambs' nutrient requirements for optimal growth are not met before weaning, but ad libitum access to nutrients during the postweaning period results in rapid catch-up growth. Compensatory growth after weaning in twin lambs has been reported extensively (Ch'ang and Rae, 1970; Lu et al., 1988; Komlósi 2008). Similar to the results of this study, Iveya et al. (2000) reported that the limited milk intake of twin lambs can hasten the development and improve the function of the digestive system in the early post-weaning period (Hamada et al., 1976) and stimulate solid feed consumption (Lu et al., 1988). Weaning shock can be reduced when lambs are fed restricted amounts of milk and encouraged to increase solid feed consumption.

\section{CONCLUSION}

We found no substantial effects of dam age on body size, except for rump length and front cannon bone cir- 
cumference, in Malya lambs during the first year of life. Singleton lambs were larger than twins until about 6 months of age, but after 9 months the size differences between singleton and twin lambs disappeared. Thus, if farmers are able to feed enough milk to twin lambs to allow them to survive until weaning, they can expect compensatory body growth after 9 months of age. Lamb gender strongly affected body size, with males being consistently larger than females in all dam age groups. This was likely due to the presence of androgens, especially testosterone.

\section{ACKNOWLEDGMENTS}

This research was supported by the Scientific Research Project Coordination Unit of Kırıkkale University (Project number 2011/38). The authors are grateful to assistants at the Research Project Coordination Unit of Kırıkkale University and housekeeper Mehmet Gevrek, shepherd Kaya Turan Kaya, veterinarian Kadir Gökhan Yıldırım, and their families for their support.

\section{REFERENCES}

Akçapınar H 1994. Koyun yetiştiriciliği (sheep breeding). I. Baskı. Medisan yayın Serisi, No: 8, Ankara

Akçapınar, H., Özbeyaz, C. 1999. Hayvan yetiştiriciliği temel bilgileri. ISBN: 975-96978-0-7, Kariyer Matbaacllk Ltd. Şti., Ankara, pp. 95-105

Bela, B., and A. Haile (2009). Factors affecting growth performance of sheep under village management conditions in the south western part of Ethiopia. Livest. Res. Rural Dev. 21(11); 128185

Baneh H, Rokouei M, Ghafouri-Kesbi F, Veysi A, Niknafs S. (2013). Multivariate genetic analysis on body weight traits in Ghezel sheep. Songklanakarin J. Sci. Technol. 35(2); 131-135

Bıyıkoğlu K 2009. Genel zootekni, Atatürk Üniversitesi Yayınları, No $\mathbf{2 3 1} ; 285-288$

Çetin $\mathrm{H}$ and Akçapınar $\mathrm{H}$ 2005. The Effects of twice lambing in a year on the survival ability and growth of Merino lambs. Lalahan Hayvancıllk Araştırma Enstitüsü Dergisi 45; 25-34

Ch'ang TS and Rae AL 1970. The genetic basis of growth, reproduction, and maternal environment in Romney ewes, Australian Journal of Agricultural Research 21; 115-129

Çolakoğlu N and Özbeyaz C 1999. Comparison of Some Production Traits in Malya and Akkaraman Sheep. Tr. J. of Veterinary and Animal Sicences, 23; 351-360

Duncan, D. B., 1955. Multiple Range and Multiple F Tests. In: Biometrics, 11; $1-42$

Düzgüneş O and Pekel E 1966. Orta Anadolu şartlarında çeşitli Akkaraman X Merinos melezlerinin verimle ilgili özellikleri üzerinde mukayeseli araştırmalar. T. B. T. A. Kurumu Proje No VHAG-6 (not in press)

Esen F and Ylldı N 2000. Production characteristics of White karaman, Chios X White Karaman (F1) crossbred Lambs. I. growth, survival ability and body Measures. Turk J Vet Anim Sci. 24 223-231

Hamada T, Maeda S and Kameoka K 1976. Factors influencing growth of rumen, liver and other organs in kids weaned from milk replacers to solid foods. J. Dairy Sci. 59; 1110-1119

Hyatt, M. A., D. H. Keisler, H. Budge, and M. E. Symonds 2010 Maternal parity and its effect on adipose tissue deposition and endocrine sensitivity in the postnatal sheep. Journal of endocrinology 204; 173-179

Işık S 2010. Bafra koyununun (Sakız x Karayaka G1) Kazım Karabekir Tarım İşletmesi şartlarında döl verimi, yaşama gücü ve büyüme özellikleri, PhD thesis, Kafkas Üniversitesi Sağllk Bilimleri Enstitüsü, Kars

Iveya DS, Owensb FN, Sahlua T, Teha TH, Dawsonc LJ, Campbellc GA, Goetscha AL 2000. Influences of the number of fetuses and levels of $\mathrm{CP}$ and $\mathrm{ME}$ in gestation and lactation supplements on performance of Spanish does and kids during suckling and post-weaning. Small Ruminant Research 35: 123-132.

Karakuş F, 2007. Growth, fattening performance and carcass characteristics of Karakas and (Ile de france x Akkaraman B1) x Karakaş F1 and F2 crossbreed lambs.Yüzüncü Yll Üniversitesi Fen Bilimleri Enstitüsü, Zootekni Anabilim Dalı, PhD thesis, Van

Kaymakçı M, and Sönmez R 1992. Koyun yetiștiriciliği. Hasad yayıncıllk, Hayvancılık serisi; 3, Baskı Robel Ofset, İstanbul

Komlósi I 2008. Genetic parameters for growth traits of the hungarian merino and meat sheep breeds in Hungary Applied Ecology and Environmental Research, 6; 75-82

Koncağül S, Akça N, Vural ME, Karataş A and Bingöl M 2012. Zom Koyunlarını Morfolojik Özellikleri (Morphological Characteristics of Zom Sheep). Kafkas Univ Vet Fak Derg, 18 829-837

Lu CD, Potchoiba MJ, Teh TH 1988. Milk feeding and weaning of goat kids. Small Rumin. Res. 1; 105-112

Minitab 1998. Minitab reference manual (release 12. 1) for windows, Minitab, Inc. USA

Pekel E and Düzgüneş O 1966. Malya devlet üretme çiftliğinde çeşitli merinos melezleri ile akkaraman kuzularında yaşama gücü ve gelişme. Ankara Üniv. Zir. Fak. Yılllı̆̆ 1-2; 62-80

Rashidi, A. Mokhtari, M. S. Safi Jahanshahi, A. and Mohammad Abadi, M. R. 2008. Genetic parameter estimates of pre-weaning growth traits in Kermani sheep. Small Ruminant Research. 74; $165-171$

Şireli HD, Ertuğrul M 2004. The growth curves estimates of Akkaraman, Dorset Down x Akkaraman (BD1) and Akkaraman x BD1 lambs using logistic model. Tarım Bilimleri Dergisi 10 375-380

Vatankhah M. Talebi M. A. 2008. Heritability estimates and correlations between production and reproductive traits in LoriBakhtiari sheep in Iran. South African Journal of Animal Science, 38(2); 110-118 